\title{
Evaluating Reliability of the PRELOAD Rubric: Assessment of Service-Learning Course Syllabi
}

Sally L. Haack

Drake University, USA

Stacy Gnacinski

Drake University, USA

Inbal Mazar

Drake University, USA

Anisa Hansen

Drake University, USA

\section{Recommended Citation}

Haack, S. L., Gnacinski, S., Mazar, I., \& Hansen, A. (2021). Evaluating reliability of the PRELOAD rubric: Assessment of service-learning course syllabi. International Journal of Research on Service-Learning and Community Engagement, 9(1), Article 2. https://doi.org/10.37333/001c.31301 


\section{Evaluating Reliability of the PRELOAD Rubric: Assessment of Service-Learning Course Syllabi}

\author{
Sally L. Haack, Stacy Gnacinski, \\ Inbal Mazar, y Anisa Hansen
}

The increase of service-learning (S-L) integration in academia warranted the development of faculty resources to facilitate course design that incorporate S-L experiences in an integrated, reciprocal, contextualized, and reflective manner. To respond to this need, Kieran and Haack (2018) created the PRELOAD rubric, a tool to evaluate service-learning course syllabi. In order to assess this rubric as an evidence-based service-learning tool, the current research measured the interrater reliability of PRELOAD. Four S-L experts, who served as raters, applied PRELOAD to a standardized set of 25 syllabi. The results of the study provide guidance for the use of the PRELOAD rubric in practice.

Keywords: assessment, PRELOAD rubric, service-learning, syllabi

\section{Valoración de la fiabilidad de los criterios PRELOAD: Evaluación de programas con un componente de aprendizaje-servicio}

\author{
Sally L. Haack, Stacy Gnacinski, \\ Inbal Mazar, y Anisa Hansen
}

El auge del aprendizaje-servicio como criterio académico ha garantizado el desarrollo de recursos del profesorado para facilitar un diseño curricular que incorpore experiencias de aprendizaje-servicio de una manera reflexiva, integrada, recíproca y contextualizada. Como respuesta a esta creciente demanda, Kieran y Haack (2018) han creado la plantilla de evaluación PRELOAD, una herramienta para evaluar programas que incluyen un componente de aprendizaje-servicio. Para evaluar esta plantilla como una herramienta de aprendizajeservicio basada en evidencia, el presente estudio mide la fiabilidad entre calificadores de PRELOAD. Cuatro expertos en aprendizajeservicio sirvieron como evaluadores y aplicaron la plantilla PRELOAD a un grupo de veinticinco programas estandarizados. Los resultados del estudio se presentan como guía orientadora para el uso de la plantilla PRELOAD

Palabras clave: evaluación, criterios PRELOAD, aprendizaje-servicio, programas 
Service-learning (S-L) in higher education continues to expand as institutions devote increased resources to strengthen the service-learning infrastructure on campus, thus enhancing the quantity and quality of courses offered. In their review of literature on the impact of S-L on students, faculty, institutions, and communities, Eyler et al. (2001) found that although faculty reported satisfaction with the quality of student learning and were increasingly integrating S-L into their courses, they viewed the lack of available resources and lack of faculty rewards as barriers. Since that paper was published, many academic institutions have taken measures to incorporate S-L in their mission and add community engagement centers to support the infrastructure of this work on college campuses. Through these centers, institutions have established faculty incentives, such as awards, grants, workshops, and learning communities, and they have created and disseminated resources (Welch \& Saltmarsh, 2013). Institutional support has further been extended to include student, faculty, and staff membership in national and international civic engagement coalitions, such as Campus Compact. These organizations have provided faculty with workshops and documents that guide the process of S-L course creation. Faculty development in S-L is important for several reasons, including defining a common vocabulary, maintaining academic integrity, increasing support and confidence, and institutionalizing the practice (Bringle \& Hatcher, 1995).

\section{The Course Syllabus}

In relation to faculty development, one key component of S-L is the proper construction of a course syllabus as the road map for achieving target learning outcomes. A survey of faculty showed that most faculty learned to write syllabi either from unofficial templates or informal experience while they were students (Fink, 2011). Fink also found that most faculty indicated that syllabus composition had a positive effect on student learning. The learning objectives, content, instructional resources, required assignments, and assessment methods help faculty frame the course and therefore should be included in the syllabus. Previous work has contrasted what should be in syllabi with what is actually found in syllabi, and emerging discrepancies point to a developmental need for faculty to create more comprehensive, inclusive, studentcentered and robust syllabi (Doolittle \& Siudzinski, 2010). In addition to the serving as a communication tool for an individual course, syllabi content may be evaluated for institutional benchmarking in certain priority areas, such as core curriculum learning outcomes, assessment methods, or pedagogical approaches (Bers et al., 1996; Eberly et al., 2001; Graves et al., 2010; McGowan et al., 2016). Syllabi are also commonly used for assessing programmatic outcomes through curricular mapping exercises (Adams et al., 2018; Arafeh, 2016; Mazouz \& Crane, 2013).

\section{Syllabi Assessment}

Previous research, outside the field of S-L, has used rubrics and checklists to evaluate syllabi as a method of analyzing course content (Cullen \& Harris, 2009; Dou et al., 2019; Lin, 2010). The simplest versions of these tools provide a checklist of items to include in the syllabus (Johnson, 2006), while others focus on syllabus elements such as tone, professional appearance, clarity of communication, and studentcenteredness (Chism, 2007). A syllabus rubric used at the University of West Florida divided criteria into two sections: required components and best practice components (Stanny et al., 2015). The study did not assess the instrument's reliability, but researchers held calibration meetings to determine interrater agreement and amended rubric guidelines with notes to maintain consensus for future decisions.

Another syllabus rubric evaluated four elements: learning goals and objectives, assessment activities, schedule, and overall learning environment (Palmer et al., 2014). Palmer et al. have described the design and rationale for their syllabus rubric but presented no evidence regarding the reliability of the rubric. These studies show that assessment strategies using course syllabi are commonplace, yet evaluation of the assessment tools themselves are rare. 


\section{Service-Learning Syllabi Assessment}

Although resources related to course syllabi and rubrics to evaluate S-L courses were available, up to 2018 there were no published rubrics available to evaluate S-L syllabi. TheIndiana University-Purdue University Indianapolis (IUPUI) Taxonomy for Service-Learning Courses is a rubric to evaluate courses thoroughly, but it was not designed for assessment of course syllabi (Hahn et al., n.d.). Although not a rubric, the first-letter mnemonic O.P.E.R.A. model provides a framework for evidence-based principles for enumerating objectives $(\mathrm{O})$, exploring partnerships $(\mathrm{P})$, identifying the type of service-learning in which students will be engaged (E), facilitating reflection (R), and assessing (A) when constructing S-L syllabi (Welch, 2010).

Additionally, works by Heffernan (2001) and Jacoby (2015) have described elements that distinguish S-L syllabi from traditional syllabi and guide instructions on how to create effective S-L syllabi. The IUPUI Center for Service and Learning website also contains some general recommendations for designing syllabi (IUPUI, n.d.). These valuable resources were consulted in the development of PRELOAD, a rubric created to provide more objectivity in evaluating courses for quality elements of S-L and to be a resource for individual faculty designing S-L courses (Kieran \& Haack, 2018).

\section{PRELOAD Rubric}

The PRELOAD rubric is based on high-impact factors in S-L and includes the following elements: partnership, reflection, engagement, logistics, objectives, assessment of student outcomes, and definition of S-L (Kieran \& Haack, 2018). Following the initial construction of PRELOAD, psychometric testing of the rubric was pursued to determine the most appropriate uses for the instrument and to guide practical application in the field. The first step in this process was to assess PRELOAD's content validity. Based on referrals from Iowa Campus Compact, 10 faculty members from various institutions across the United States were invited to participate. They all had experience either teaching S-L courses or directing community engagement offices in higher education. They were asked to comment on the relevancy of the 7 constructs of PRELOAD and the clarity of the criteria within each rubric cell. Additionally, they offered suggestions for revisions and applications for rubric use. The reviewers were also given two sample syllabi and asked to submit the corresponding rubric evaluations.

Based on participant feedback, the following revisions were made to the rubric to improve its accuracy and ease of use: clarifying criteria, formatting cells, revising phrases for consistency, altering the rubric anchors (column titles), and changing rubric spacing. The next step in the series of PRELOAD validation studies was to assess interrater reliability, or the level of agreement in raters' categorical responses to rubric elements across a series of syllabi. The purpose of the current study is to evaluate the interrater reliability of the PRELOAD rubric as an evidence-based method for assessing S-L course syllabi.

\section{Methods}

\section{Raters}

Study participants were recruited based on their recognition as experts in the field of S-L. Iowa Campus Compact sent the researchers a list of people who met this criterion. The researchers invited them to participate and informed them that they would receive $\$ 300$ as compensation upon completion of their requirements as raters. The first individuals who responded with interest were included in the study. The cohort of raters consisted of three S-L staff and one faculty member. One rater was a program manager for a state Campus Compact; two were assistant directors of community engagement offices (one from a small, private university and the other from a midsized public university); and one was a library faculty member at a midsized public university. All raters had previous experience completing five or more S-L professional development sessions and indicated they had led S-L workshops or sessions. Upon agreeing to participate, they were provided with all study materials through a shared network drive and given one month to complete the syllabus ratings. This study was approved by the university's Institutional Review Board. 
4 | International Journal of Research on Service-Learning and Community Engagement

\section{Measure}

Interrater reliability was assessed for each element of the PRELOAD rubric. The rubric asks raters to evaluate the syllabus based on 7 elements: partnership, reflection, engagement, logistics, objectives, assessment of student outcomes, and definition of S-L. References that support each criterion's creation regarding evidence-based best practices are included for each element. The rater then assigns an evaluation of the element based on the three available options: developing, satisfactory, and excellent. The assigned ratings reflect how closely the syllabus aligns with the research base for S-L pedagogy.

The PRELOAD rubric evaluates syllabi only, and raters are instructed to not make assumptions about what is explicitly stated or not stated. Each element is assessed independently and there is not a summative syllabus score for the PRELOAD rubric.

\section{Procedures}

For this study, raters were asked to partake in the online training module and then provide rubric ratings. The research team developed an online training module for PRELOAD users, which defined each element of the rubric and explained the criteria of each rubric cell. Study raters viewed this short, less than onehour, online training module to be oriented to PRELOAD. The video module contained a brief background of S-L, an orientation to the rubric, and application of the rubric. Additionally, the training module showed examples with sample syllabi to improve consistency in the criteria application, leaving less up to user interpretation. At the conclusion of the video, raters received instructions and the scoring process for the research study.

Twenty-five sample syllabi, representing graduate and undergraduate courses from a variety of disciplines and from both public and private institutions, were selected from a Campus Compact syllabi repository. Half of the syllabi originated from institutions recognized with the Carnegie Classification for Community Engagement with representation from individual service, small group service, and international service. All four raters scored the same 25 syllabi using a Qualtrics survey platform. Raters were instructed to not make any assumptions regarding course activities beyond what was explicitly stated in the syllabi, which were de-identified prior to distribution.

\section{Data Analysis}

To determine the interrater reliability of the PRELOAD rubric, two different statistical computations were performed. Given the ordinal level of measurement for the PRELOAD rubric, the mean of Spearman's rho correlation coefficients was computed for each rubric element to determine the rank-order consistency across raters (Furr, 2018). Mean rank correlations of $0.0-0.3$ were considered weak, $0.3-0.7$ were considered moderate, and 0.7-1.0 were considered strong. Furr suggested that low rho correlations may indicate construct bias, in which the test can have different meanings for different groups. In addition, Fleiss' kappas were computed to determine the proportion of agreement between raters' scores for each rubric element across all 25 syllabi (Azen \& Walker, 2011).

Kappa values were interpreted as follows: $\kappa<0.20$ are poor, $0.21<\kappa<0.40$ are fair, $0.41<\kappa<0.60$ are moderate, $0.61<\kappa<0.80$ are good, and $\kappa>0.81$ are excellent. There are no standardized guidelines for interpretation; it is widely accepted that kappas above 0.60 demonstrate an acceptable level of interrater agreement (Hernaez, 2015). If the 95\% confidence intervals did not include zero, interrater agreement was interpreted as being significantly better than chance. Kappas are considered a suitable measure of interrater agreement for categorical data, as the computation reflects the proportion of agreement between raters while accounting for the probability of random chance agreement. 


\section{Results}

As shown in Table 1, the Spearman's rho correlation coefficients indicated a moderate level of association between raters' rubric element responses across the 25 syllabi. Based on the Fleiss' kappa computations, poor to fair levels of interrater agreement were observed for each rubric element across all syllabi. As part of the Fleiss' kappa analysis, individual kappa values were computed for individual categories. The results presented in Table 2 indicate that raters' level of agreement did not appear to be impacted by the categorical response options. Thus, these data demonstrate that raters inconsistently applied categorical ratings of developing, satisfactory, or excellent across syllabi. Overall, the findings do not support the use of the PRELOAD rubric for scientific or standardized assessment whereby interrater reliability is essential.

\section{Table 1}

Interrater Reliability of Rubric Scoring

\begin{tabular}{lcc}
\hline Rubric Element & $\begin{array}{c}\text { Spearman's Rho Correlation Coefficient } \\
\text { (magnitudes only) }\end{array}$ & Fleiss' Kappa \pm SE (95\% CI) \\
\hline Partnership & 0.441 & $0.245 \pm 0.058(0.242,0.249)$ \\
Reflection & 0.452 & $0.259 \pm 0.064(0.255,0.263)$ \\
Engagement & 0.501 & $0.329 \pm 0.058(0.325,0.333)$ \\
Logistics & 0.510 & $0.224 \pm 0.071(0.220,0.229)$ \\
Outcomes & 0.361 & $0.190 \pm 0.062(0.186,0.194)$ \\
Assessment & 0.345 & $0.165 \pm 0.062(0.161,0.169)$ \\
Definition & 0.444 & $0.240 \pm 0.077(0.235,0.244)$ \\
\hline
\end{tabular}

Table 2

Level of Agreement Across Individual Rubric Category Responses

Kappa for Individual Categories (95\% CI)

\begin{tabular}{lccc}
\hline Rubric Element & Developing & Satisfactory & Excellent \\
Partnership & $0.288(0.128,0.448)$ & $0.081(-0.079,0.241)$ & $0.376(0.216,0.536)$ \\
Reflection & $0.453(0.293,0.613)$ & $0.201(0.041,0.361)$ & $-0.073(-0.233,0.087)$ \\
Engagement & $0.334(0.174,0.495)$ & $0.173(0.013,0.333)$ & $0.520(0.360,0.680)$ \\
Logistics & $0.307(0.147,0.467)$ & $0.191(0.031,0.351)$ & $-0.042(-0.202,0.118)$ \\
Outcomes & $0.114(-0.046,0.274)$ & $0.111(-0.049,0.271)$ & $0.302(0.142,0.462)$ \\
Assessment & $0.178(0.018,0.338)$ & $0.111(-0.049,0.271)$ & $0.242(0.082,0.402)$ \\
Definition & $0.306(0.146,0.466)$ & $0.311(0.030,0.350)$ & $-0.010(-0.170,0.150)$ \\
\hline
\end{tabular}




\section{Discussion}

The purpose of this study was to evaluate interrater reliability of the PRELOAD rubric as an evidencebased method for assessing S-L course syllabi. Results demonstrate a moderate association between raters' rubric element responses across the 25 syllabi, meaning that raters inconsistently applied the categorical ratings when using the PRELOAD rubric. These results suggest that the PRELOAD rubric requires additional development if the tool were to be used for assessment purposes.

Rubrics are used to assess the performance of activities in a structured way; therefore, testing these properties through multiple studies is important to ensure that they are measuring content in an accurate and consistent manner. Unfortunately, some of the most widely used tools do not undergo psychometric evaluation (Bernat-Adell et al., 2019). S-L is no exception, and therefore it is difficult to compare this novel study with other psychometric assessments in the field. Existing tools, such as the O.P.E.R.A model (Welch, 2010), Ballard and Ellmore's (2009) syllabus checklist, and IUPUI (n.d.) resources, support S-L syllabi design, but they haven't been evaluated for their validity or reliability. This study is a step towards providing information about how PRELOAD should be utilized. It also expands S-L assessment, which is critical to ensuring consistent quality of experiences, developing arguments for additional resources and documenting outcomes to share with others. Despite these benefits, assessment and evaluation are often avoided in S-L (Holland, 2001).

Our collective body of work aims to advance the field of S-L by providing evidence-based recommendations for not only current use but also to guide and direct future research utilizing the PRELOAD rubric. As previously noted, most faculty have minimal formal training in writing syllabi (Fink, 2011). It is important to recognize that although most of the research surrounding faculty development focuses on structured, formal programs, such as workshops, faculty cohort models, guest speakers or learning communities, it is also valuable to expand the resources for self-directed faculty learning. In these settings, PRELOAD can be used by individual faculty and staff members to evaluate their own courses or to design new courses. Regardless of interrater reliability results, the PRELOAD rubric is grounded in evidence-based literature and can be used to recognize direct application of these best practices in a tangible manner with syllabus creation or revision. This self-reflective, individualized development exercise continues to be appropriate for individual faculty members seeking to improve their S-L courses using the PRELOAD rubric.

It is also important to recognize that the raters in this study were all experts in the field of S-L and therefore all had working knowledge of the elements that the PRELOAD rubric is designed to assess. Additionally, they were provided with a short training module that oriented them to the rubric and its application. Despite these factors, the results of our study demonstrated only moderate levels of correlation between raters. It may be worthwhile to more closely examine why certain elements had higher rho correlations $(>0.5)$, such as engagement and logistics, than other elements, such as assessment (0.345) and outcomes (0.361). Although these differences may be a result of construct bias in the rubric, they may reflect areas for development in the field. In the example of the assessment element, the raters must distinguish between the types of growth the student experiences (affective, behavioral, or cognitive). This may be more complicated for raters to score than other elements, such as the logistics element that includes criteria like time commitment expectations for S-L activities.

Although rubrics reduce complexity and enhance objectivity of evaluations, the results of this study show that the PRELOAD rubric should not be used to provide summative feedback to faculty about their courses. The data from this study also do not support the use of PRELOAD by the promotion and tenure committee or for departmental evaluations. Whereas the strengths in PRELOAD lie in its ability to guide faculty development as S-L practitioners, there is a need to design more reliable tools to evaluate S-L courses from a summative perspective. 


\section{Limitations}

One potential limitation of the study is related to varying fields of the syllabi, since even though all the raters were S-L experts, their interpretation of rubric details and what is implied in the syllabi may vary based on their experience. They may not have been familiar with expectations of a course or disciplinespecific language and outcomes within a certain field. Alternatively, familiarity with the field may also lead to rater bias as a result of potential subjective ratings based on personal experience and knowledge within the field. Despite being instructed not to make assumptions about what is explicitly stated or not stated in the syllabus, raters may have made assumptions about content, especially in relation to assessment.

It is also important to acknowledge that while a syllabus is helpful for understanding course objectives and intended outcomes, it may not encompass all the information shared with students, and the learning activities may be implemented differently than initially planned. For example, an instructor might design an assignment for students to interpret for non-English-speaking clients at a legal clinic, and this may not take place due to unforeseen circumstances. There is also certainly learning that occurs in a classroom that is not captured in a syllabus (Warner \& Esposito, 2009). For these reasons, the syllabus design is assessed, and not the course itself.

Another potential limitation to the study was the quantity of syllabi evaluated in relation to the time raters dedicated to evaluating may impact assessment. Raters were asked to complete 25 syllabi evaluations at their own selected pace within a month. Completion pace varied from 1 week to 1 month within the allotted period, which could have impacted the way the syllabi were scored. For instance, a rater who completes 25 rubric evaluations consecutively could become fatigued as they rate, which may affect scores, in the same way that the consecutive time instructors dedicate to reviewing assignments could affect their grading during an extensive session.

\section{Next Steps}

Since its creation in 2018, the PRELOAD rubric has undergone multiple revisions as a result of the data collected during content validity testing. Each of these revisions sought to strengthen the tool. The current study evaluated interrater reliability of PRELOAD. The analysis of the rubric gives users reliable data to provide specific settings in which it would not be fitting to use PRELOAD. There are also opportunities to tailor the rubric to more specific programs or settings where raters share similar discipline-specific knowledge and experiences. A more homogenous sample of syllabi and raters could result in improved reliability within a field or discipline.

Another opportunity for future PRELOAD research could involve studying a discipline-specific version of the rubric or using a larger sample size that allows for comparisons between disciplines. For example, the current study selected S-L experts as raters, but an alternate study might seek to recruit raters who are experts in educational pedagogy and syllabus creation. There are also opportunities to refine the rubric through revisions to organization, content, and flow, as this is an ongoing process of evaluation, refinement, and development that cannot be accomplished in a single study.

\section{Conclusion}

This study analyzes interrater reliability of the PRELOAD rubric when used to evaluate course syllabi for elements of S-L. Based on the study's findings, the rubric is likely unsuitable to be used in summative assessments and in high-stakes situations, such as promotion and tenure evaluations. This work advances the field of S-L by submitting the rubric to a rigorous evaluation process and recognizes areas to evaluate for future applications in practice.

Tools to evaluate syllabi in practice, particularly S-L syllabi, are rare, and psychometric assessments of these tools are not readily available. Therefore, it is difficult to compare these findings with similar studies. It is our hope that others will adopt the PRELOAD rubric, continue to refine it, and evaluate its optimal use in the S-L field, with the overall goal of improving the quality and facilitating the design of current and future S-L courses. In the grand scheme of syllabi development, we are also compelled to call 
8 International Journal of Research on Service-Learning and Community Engagement

others to action within and outside S-L to systematically assess syllabi in a reliable and valid manner. The development of such evidence- based assessments requires intentional and interdisciplinary efforts in future research.

\section{References}

Adams, M., Rodriguez, S., \& Zimmer, K. (2018). Studying cultural relevance in online courses: A thematic inquiry. Online Learning, 22(4), 361-381. https://.doi.org/10.24059/olj.v22i4.1262

Arafeh, S. (2016). Curriculum mapping in higher education: A case study and proposed content scope and sequence mapping tool. Journal of Further and Higher Education, 40(5), 585-611. https://doi.org/10.1080/0309877X.2014.1000278

Azen, R., \& Walker, C. M. (2011). Categorical data analysis for the behavioral and social sciences. Routledge.

Ballard, S. M., \& Elmore B. (2009). A labor of love: Constructing a service-learning syllabus. The Journal of Effective Teaching, 9(3), 70-76.

Bernat-Adell, M. D., Moles-Julio, P., Esteve-Clavero, A., \& Collado-Boira, E. J. (2019). Psychometric evaluation of a rubric to assess basic performance during simulation in nursing. Nursing Education Perspectives, 40(2), E3-E6. https://doi.org/10.1097/01.NEP.0000000000000436

Bers, T., Davis, D., \& Taylor, W. (1996). Syllabus analysis: What are we teaching and telling our students? Assessment Update: Progress, Trends, and Practices in Higher Education, 8(6), 1-14. https://doi.org/10.1002/au.3650080602

Bringle, R. G., \& Hatcher, J. A. (1995). A service-learning curriculum for faculty. Michigan Journal of Community Service Learning, 2(1), 112-122.

Chism, N. V. N. (2007). Peer review of teaching: A sourcebook. Anker.

Cullen, R., \& Harris, M. (2009). Assessing learner.centeredness through course syllabi. Assessment \& Evaluation in Higher Education, 34(1), 115-125. https://doi.org/10.1080/02602930801956018

Doolittle, P. E., \& Siudzinski, R. A. (2010). Recommended syllabus components: What do higher education faculty include in their syllabi? Journal on Excellence in College Teaching, 21(3), 2961.

Dou, R., Teodorescu, R., Madsen, A., Redish, E. F., \& Reeves, M. (2019). Examining course syllabi: Introductory physics for life sciences. Physical Review Physics Education Research, 15(2). https://doi.org/10.1103/PhysRevPhysEducRes.15.020143

Eberly, M. B., Newton, S. E., \& Wiggins, R. A. (2001). The syllabus as a tool for student-centered learning. The Journal of General Education, 50(1), 56-74. https://doi.org/10.1353/jge.2001.0003

Eyler, J., Giles, D. E., Jr., Stenson, C. M., \& Gray, C. J. (2001). At a glance: What we know about the effects of service-learning on college students, faculty, institutions and communities, 1993-2000 (3rd ed). Higher Education, 139. https://digitalcommons.unomaha.edu/slcehighered/139

Fink, S. J. (2011). An exploratory study on the purpose, structure, format and use of syllabi at a Midwest four-year undergraduate private university [Unpublished doctoral dissertation], Drake University. ProQuest. https://www.proquest.com/docview/922663743

Furr, R. M. (2018). Psychometrics: An introduction.: SAGE Publications. 
Graves, R., Hyland, T., \& Samuels, B. M. (2010). Undergraduate writing assignments: An analysis of syllabi at one Canadian college. Written Communication, 27(3), 293-317. https://doi.org/10.1177/0741088310371635

Hahn, T. W., Hatcher, J. A., Price, M. F., \& Studer, M. L. (n.d.). IUPUI taxonomy for service learning courses - course design centric for institutional assessment and research. https://scholarworks.iupui.edu/bitstream/handle/1805/10851/IUPUI\%20Taxonomy $\% 20$ for $\% 20 \%$ 20Service $\% 20$ Learning.pdf? sequence $=7 \&$ isAllowed $=\mathrm{y}$

Heffernan, K. (2001). Fundamentals of service-learning course construction. Campus Compact.

Hernaez, R. (2015). Reliability and agreement studies: A guide for clinical investigators. Gut, 64(7), 1018-1027. https://doi.org/10.1136/gutjnl-2014-308619

Holland, B. A. (2001). A comprehensive model for assessing service-learning and community- universitypartnerships. New Directions for Higher Education, 114, 51-60.

IUPUI. (n.d.). Syllabus design for service learning. Retrieved October 1, 2021, from the IUPUI Center for Service and Learning website, https://csl.iupui.edu/teaching-research/curriculum/coursedesign/syllabus/index.html

Jacoby, B. (2015). Service-learning essentials: Questions, answers, and lessons learned. Jossey-Bass.

Johnson, C. (2006). Best practices in syllabus writing: Contents of a learner-centered syllabus. Journal of Chiropractic Education, 20(2), 139-144. https://doi.org/10.7899/1042-5055-20.2.139

Kieran L., \& Haack S. (2018). PRELOAD: A rubric to evaluate course syllabi for quality indicators of community engagement and service-learning components. Journal of Community Engagement and Higher Education, 10(2), 39-47.

Lin, B. (2010). An assessment of undergraduate course syllabi in the departments of English at universities in Taiwan. ProQuest. https://digital.library.unt.edu/ark:/67531/metadc28451/

Mazouz, A., \& Crane, K. (2013). Application of matrix outcome mapping to constructively align program outcomes and course outcomes in higher education. Journal of Education and Learning, 2(4), 166-176. https://doi.org/10.5539/jel.v2n4p166

McGowan, B., Gonzalez, M., Stanny, C. J. (2016). What do undergraduate course syllabi say about information literacy? Libraries and the Academy, 16(3), 599-617. https://doi.org/10.1353/pla.2016.0040

Palmer, M. S., Bach, D. J., \& Streifer, A. C. (2014). Measuring the promise: A learning.focused syllabus rubric. To Improve the Academy: A Journal of Educational Development, 33(1), 14-36. https://doi.org/10.1002/tia2.20004

Stanny, C., Gonzalez, M., \& McGowan, B. (2015). Assessing the culture of teaching and learning through a syllabus review. Assessment \& Evaluation in Higher Education, 40(7), 898-913. https://doi.org/10.1080/02602938.2014.956684

Warner, B., \& Esposito, J. (2009). What's not in the syllabus: Faculty transformation, role modeling and role conflict in immersion service-learning courses. International Journal of Teaching and Learning in Higher Education, 20(3), 510-517.

Welch, M. (2010). O.P.E.R.A.: A first letter mnemonic and rubric for conceptualising and implementing S-L. Issues in Educational Research, 20(1), 76-82.

Welch, M., \& Saltmarsh J. (2013). Current practice and infrastructures for campus centers of community engagement. Journal of Higher Education Outreach and Engagement, 17(4), 25-55. 


\section{Appendix}

\section{The PRELOAD Rubric}

\begin{tabular}{|c|c|c|c|}
\hline $\begin{array}{l}\text { Reflected within the course } \\
\text { syllabus }\end{array}$ & $\begin{array}{l}\text { Excellent } \\
\text { Thoroughly incorporates key } \\
\text { components of } S \text {-L pedagogy }\end{array}$ & $\begin{array}{l}\text { Satisfactory } \\
\text { Aligns with the research base for } S-L \\
\text { pedagogy }\end{array}$ & $\begin{array}{l}\text { Developing } \\
\text { Does not clearly include key aspects of } S \text { - } \\
\text { L pedagogy }\end{array}$ \\
\hline $\begin{array}{l}\text { Partnership } \\
\text { (Note: the rubric focus is on } \\
\text { student-centered aspects that } \\
\text { are expected to be included in a } \\
\text { syllabus) } \\
\text { (Porter-Honnet \& Poulsen, } \\
\text { 1990; Tinkler, et al., 2014; } \\
\text { Welch, 2010) }\end{array}$ & $\begin{array}{l}\text { All of the following are evident: } \\
\text { Students have an active role in planning } \\
\text { S-L activities } \\
\text { AND } \\
\text { Students have multiple opportunities to } \\
\text { work with the S-L partner (in the } \\
\text { classroom and/or community) } \\
\text { AND } \\
\text { Activities are aligned with partner's } \\
\text { needs and course's learning outcomes }\end{array}$ & $\begin{array}{l}\text { Two of the following are evident: } \\
\text { Students have an active role in } \\
\text { developing S-L activities } \\
\text { OR } \\
\text { Students have multiple opportunities to } \\
\text { work with the S-L partner (in the } \\
\text { classroom and/or community) } \\
\text { OR } \\
\text { Activities are aligned with partner's } \\
\text { needs and course's learning outcomes }\end{array}$ & $\begin{array}{l}\text { 0-1 of the following are evident: } \\
\text { Students have an active role in } \\
\text { developing S-L activities } \\
\text { OR } \\
\text { Students have multiple opportunities to } \\
\text { work with the S-L partner (in the } \\
\text { classroom and/or community) } \\
\text { OR } \\
\text { Activities are aligned with partner's } \\
\text { needs and course's learning outcomes }\end{array}$ \\
\hline $\begin{array}{l}\text { Reflection } \\
\text { (Bringle \& Hatcher, 1995; } \\
\text { Eyler, 2002; Jacoby, 2015; } \\
\text { Kolb, 1984; Mesirow, 1998; } \\
\text { Porter-Honnet \& Poulsen, 1990; } \\
\text { Welch, 2010) }\end{array}$ & $\begin{array}{l}\text { All of the following are evident: } \\
\text { Students have multiple opportunities for } \\
\text { reflection, based on observations and } \\
\text { shaped by instructor and peer feedback } \\
\text { AND } \\
\text { Students reflect on assumptions, make } \\
\text { meaning from their experiences, and } \\
\text { apply new understandings } \\
\text { AND } \\
\text { Reflection connects instructional and } \\
\text { civic engagement outcomes }\end{array}$ & $\begin{array}{l}\text { Reflection is ongoing and occurs at } \\
\text { multiple points of the project } \\
\text { AND } \\
\text { Two of the following are evident: } \\
\text { Reflection is shaped by instructor or peer } \\
\text { feedback } \\
\text { OR } \\
\text { Students reflect on assumptions, and } \\
\text { make meaning from their experiences to } \\
\text { develop new understandings } \\
\text { OR } \\
\text { Reflection is connected to instructional } \\
\text { objectives/learning outcomes }\end{array}$ & $\begin{array}{l}\text { 0-2 of the following are evident: } \\
\text { Reflection occurs at multiple points in } \\
\text { the project } \\
\text { OR } \\
\text { Reflection is shaped by instructor or peer } \\
\text { feedback } \\
\text { OR } \\
\text { Students are encouraged to make } \\
\text { meaning of their experiences } \\
\text { OR } \\
\text { Reflection is connected to instructional } \\
\text { objectives/learning outcomes }\end{array}$ \\
\hline
\end{tabular}




\begin{tabular}{|c|c|c|c|}
\hline $\begin{array}{l}\text { Reflected within the course } \\
\text { syllabus }\end{array}$ & $\begin{array}{l}\text { Excellent } \\
\text { Thoroughly incorporates key } \\
\text { components of } S \text { - L pedagogy }\end{array}$ & $\begin{array}{l}\text { Satisfactory } \\
\text { Aligns with the research base for } S-L \\
\text { pedagogy }\end{array}$ & $\begin{array}{l}\text { Developing } \\
\text { Does not clearly include key aspects of } S \\
\text { L pedagogy }\end{array}$ \\
\hline $\begin{array}{l}\text { Engagement } \\
\text { (Jacoby, 2015; Welch, 2010) }\end{array}$ & $\begin{array}{l}\text { Students are active participants } \\
\text { throughout the S-L project: they are } \\
\text { engaged with all } 4 \text { of the following: } \\
\text { - the instructor, } \\
\text { - themselves (reflection), } \\
\text { - peers (collaboration/ feedback), and } \\
\text { - the community partner (which may } \\
\text { include service activities and critical } \\
\text { reflection) } \\
\text { in organized activities designed to } \\
\text { facilitate learning }\end{array}$ & $\begin{array}{l}\text { Students are mostly active participants } \\
\text { throughout the S-L project: they are } \\
\text { engaged with } \mathbf{3} \text { of the following: } \\
\text { - the instructor } \\
\text { - themselves (reflection), } \\
\text { - peers (collaboration/ feedback), and } \\
\text { - the community partner (which may } \\
\text { include service activities and critical } \\
\text { reflection) } \\
\text { in organized activities designed to } \\
\text { facilitate learning }\end{array}$ & $\begin{array}{l}\text { Students are not active participants } \\
\text { throughout the S-L project: they are } \\
\text { engaged with } \mathbf{2} \text { or fewer of the } \\
\text { following: } \\
\text { - the instructor, } \\
\text { - themselves (reflection), } \\
\text { - peers (collaboration/ feedback), and } \\
\text { - the community partner (which may } \\
\text { include service activities and critical } \\
\text { reflection) } \\
\text { in organized activities designated to } \\
\text { facilitate learning } \\
\text { OR } \\
\text { There are not clearly organized activities } \\
\text { related to the course outcomes and/or the } \\
\text { community partners' needs }\end{array}$ \\
\hline $\begin{array}{l}\text { Logistics } \\
\text { (Bringle \& Hatcher, 1995; } \\
\text { Porter-Honnet \& Poulsen, } \\
\text { 1990) } \\
\text { (Note: there are many logistics } \\
\text { that must be considered in } \\
\text { setting up S-L partnerships; the } \\
\text { logistics within this rubric are } \\
\text { specifically related to the } \\
\text { project implementation with } \\
\text { students) }\end{array}$ & $\begin{array}{l}\text { All } 3 \text { are evident: } \\
\text { Students have varied ways in which they } \\
\text { can engage in S-L, the time commitment } \\
\text { expectations are clear (required vs. } \\
\text { optional service activities are clearly } \\
\text { stated) } \\
\text { AND } \\
\text { Expectations such as site-based } \\
\text { requirements (behavior, dress, etc) are } \\
\text { outlined; when applicable, students' } \\
\text { safety or security precautions are } \\
\text { addressed } \\
\text { AND } \\
\text { A statement regarding failure to } \\
\text { satisfactorily meet expectations is } \\
\text { included (i.e.: incomplete service, } \\
\text { inappropriate behavior) }\end{array}$ & $\begin{array}{l}\text { Two of the following are evident: } \\
\text { Students have varied ways in which they } \\
\text { can engage in S-L, the time commitment } \\
\text { expectations are clear (required vs. } \\
\text { optional service activities are clearly } \\
\text { stated) } \\
\text { OR } \\
\text { Expectations such as site-based } \\
\text { requirements (behavior, dress, etc) are } \\
\text { outlined; when applicable, students' } \\
\text { safety or security precautions are } \\
\text { addressed } \\
\text { OR } \\
\text { A statement regarding failure to } \\
\text { satisfactorily meet expectations is } \\
\text { included (i.e.: incomplete service, } \\
\text { inappropriate behavior) }\end{array}$ & $\begin{array}{l}\text { 0-1 of the following are evident: } \\
\text { Students have varied ways in which they } \\
\text { can engage in S-L, the time commitment } \\
\text { expectations are clear (required vs. } \\
\text { optional service activities are clearly } \\
\text { stated) } \\
\text { OR } \\
\text { Expectations such as site-based } \\
\text { requirements (behavior, dress, etc) are } \\
\text { outlined; when applicable, students' } \\
\text { safety or security precautions are } \\
\text { addressed } \\
\text { OR } \\
\text { A statement regarding failure to } \\
\text { satisfactorily meet expectations is } \\
\text { included (i.e.: incomplete service, } \\
\text { inappropriate behavior) }\end{array}$ \\
\hline
\end{tabular}




\begin{tabular}{|c|c|c|c|}
\hline $\begin{array}{l}\text { Reflected within the course } \\
\text { syllabus }\end{array}$ & $\begin{array}{l}\text { Excellent } \\
\text { Thoroughly incorporates key } \\
\text { components of } S \text { - } L \text { pedagogy }\end{array}$ & $\begin{array}{l}\text { Satisfactory } \\
\text { Aligns with the research base for } S-L \\
\text { pedagogy }\end{array}$ & $\begin{array}{l}\text { Developing } \\
\text { Does not clearly include key aspects of } S \text { - } \\
\text { L pedagogy }\end{array}$ \\
\hline $\begin{array}{l}\text { Outcomes } \\
\text { (Howard, 2001; Kuh, 2008; } \\
\text { Porter-Honnet \& Poulsen, 1990; } \\
\text { Welch, 2010) }\end{array}$ & $\begin{array}{l}\text { The learning outcomes are clearly tied to } \\
\text { S-L pedagogy and S-L activities. The } \\
\text { objectives are content-centered } \\
\text { (academic) as well as student-centered } \\
\text { (behavioral or affective outcomes) }\end{array}$ & $\begin{array}{l}\text { The learning outcomes can be met with } \\
\text { S-L pedagogy. } \\
\text { The objectives are either content- } \\
\text { centered (academic) OR student-centered } \\
\text { (behavioral or affective outcomes) }\end{array}$ & $\begin{array}{l}\text { The learning outcomes cannot be met } \\
\text { with S-L pedagogy }\end{array}$ \\
\hline $\begin{array}{l}\text { Assessment of students' } \\
\text { outcomes } \\
\text { (Note: community outcomes } \\
\text { should be evaluated separately } \\
\text { from student outcomes) } \\
\text { (Howard, 2001; Welch, 2010) }\end{array}$ & $\begin{array}{l}\text { Both of the following are evident: } \\
\text { Assessment occurs before, during, and } \\
\text { after service activities to provide a } \\
\text { baseline and evaluate students' progress } \\
\text { formatively during the service activities } \\
\text { AND } \\
\text { Assessment is used to evaluate affective } \\
\text { and behavioral growth, as well as } \\
\text { cognitive growth on academic standards. }\end{array}$ & $\begin{array}{l}\text { Assessment occurs at multiple points of } \\
\text { the S-L project. } \\
\text { BUT } \\
\text { The assessment does not evaluate } \\
\text { students' affective, behavioral, and } \\
\text { cognitive growth }\end{array}$ & $\begin{array}{l}\text { Assessment occurs at one point of the S- } \\
\text { L project } \\
\text { OR } \\
\text { The frequency of assessment is not } \\
\text { clearly stated }\end{array}$ \\
\hline $\begin{array}{l}\text { Definition of S-L } \\
\text { (Bringle \& Hatcher, 1995; } \\
\text { Jacoby, 2015) }\end{array}$ & $\begin{array}{l}\text { All of the following are evident: } \\
\text { The institution's definition of S-L is } \\
\text { explicitly stated in the syllabus } \\
\text { AND } \\
\text { Stated benefits of using S-L pedagogy to } \\
\text { meet the intended learning outcomes } \\
\text { AND } \\
\text { There is a statement connecting the S-L } \\
\text { pedagogy in the class to the university's } \\
\text { S-L goals or values }\end{array}$ & $\begin{array}{l}\text { Two of the following are evident: } \\
\text { The institution's definition of S-L is } \\
\text { explicitly stated in the syllabus } \\
\text { OR } \\
\text { Stated benefits of using S-L pedagogy to } \\
\text { meet the intended learning outcomes } \\
\text { OR } \\
\text { There is a statement connecting the S-L } \\
\text { pedagogy in the class to the university's } \\
\text { goals or values }\end{array}$ & $\begin{array}{l}\text { 0-1 of the following are evident: } \\
\text { The institution's definition of S-L is } \\
\text { explicitly stated in the syllabus } \\
\text { OR } \\
\text { Stated benefits of using S-L pedagogy to } \\
\text { meet the intended learning outcomes } \\
\text { OR } \\
\text { There is a statement connecting the S-L } \\
\text { pedagogy in the class to the university's } \\
\text { goals or values }\end{array}$ \\
\hline
\end{tabular}




\begin{abstract}
About the Authors
Sally Haack, PharmD, is a professor of pharmacy practice at Drake University.

Stacy Gnacinski, PhD, CMPC, is an assistant professor of health sciences at Drake University.

Inbal Mazar, Ph.D., is an associate professor of Spanish at Drake University.

Anisa Hansen, PharmD, is a professor of pharmacy practice at Drake University.

Correspondence concerning this article should be addressed to Sally L. Haack at sally.haack@drake.edu.
\end{abstract}

